•研究报告・

\title{
西藏沙棘5种不同组织内生细菌多样性
}

\author{
张爱梅", 殷一然, 孔维宝®, 朱学泰, 杨颖丽
}

西北师范大学生命科学学院, 兰州 730070

摘要: 西藏沙棘(Hippophae tibetana)是分布于高寒高海拔地区的一类特殊的放线菌结瘤植物, 弗兰克氏菌能够侵染其根部形 成根瘤, 因共生固氮等作用而增强其生态适应性。在西藏沙棘的根瘤中, 除了弗兰克氏菌之外还有其他内生菌, 而弗兰克氏 菌又不仅仅在根瘤中有分布。为了探究弗兰克氏菌在西藏沙棘不同组织中的定殖及可能的迁移规律, 分析不同组织中内生细 菌的群落结构及多样性, 本研究以生长在甘肃省天祝藏族自治县抓喜秀龙金强河河滩地的西藏沙棘为材料, 应用 $16 \mathrm{~S}$ rRNA 扩增子高通量测序技术, 对西藏沙棘根瘤、茎、枝、叶和种子等不同组织的内生细菌多样性进行了分析。研究结果表明, 西 藏沙棘根瘤内生细菌群落丰富度及多样性最高, 种子内生细菌群落丰富度最低, 茎内生细菌群落多样性最低。西藏沙棘5种不 同组织中的弗兰克氏菌和其他内生细菌多样性都具有一定差异, 变形菌门均为优势门, 弗兰克氏菌属(Frankia)为根瘤内生细 菌群落的优势属, 弗莱德门菌属(Friedmanniella)为茎内生细菌群落的优势属, 塞养单胞菌属(Stenotrophomonas)为枝、叶和种 子内生细菌群落的优势属。研究结果还表明, 弗兰克氏菌属不仅仅存在于西藏沙棘的根瘤, 还能够分布于其他组织, 且在同 一种组织中存在弗兰克氏菌属的不同“种”; 而在西藏沙棘不同组织中，也分布有弗兰克氏菌属的相同“种”。此外，对西藏沙 棘5种不同组织内生细菌中的功能菌株的分析表明, 不同组织中均存在着具有固氮、促生和抑菌功能的内生细菌, 但具有固氮 作用的内生细菌主要分布于根瘤, 具有促生作用以及抑菌功能的内生细菌主要分布于枝和叶。综上, 西藏沙棘5种不同组织内 生细菌具有丰富的多样性, 但各组织内生细菌的群落结构和优势种群有所不同, 且不同组织也能够定殖具有多种功能的内生 细菌。

关键词: 西藏沙棘; 组织; 内生细菌; 多样性; 弗兰克氏菌; 功能菌株

张爱梅, 殷一然, 孔维宝, 朱学泰, 杨颖丽 (2021) 西藏沙棘5种不同组织内生细菌多样性. 生物多样性, 29, 1236-1244. doi: 10.17520/biods.2021034. Zhang AM, Yin YR, Kong WB, Zhu XT, Yang YL (2021) Diversity of endophytic bacteria in five types of tissues of Hippophae tibetana. Biodiversity Science, 29, 1236-1244. doi: 10.17520/biods.2021034.

\section{Diversity of endophytic bacteria in five types of tissues of Hippophae tibetana}

\author{
Aimei Zhang*, Yiran Yin, Weibao Kong ${ }^{(\mathbb{D})}$, Xuetai Zhu, Yingli Yang ${ }^{(D)}$ \\ College of Life Sciences, Northwest Normal University, Lanzhou 730070
}

\section{ABSTRACT}

Aims: Hippophae tibetana is a special kind of actinorhizal plants distributed in severe cold and high altitude areas. Frankia spp. can infect its roots and form nodules, which enhances its ecological adaptability due to symbiotic nitrogen fixation and other effects. Besides Frankia spp., there are other endophytic bacteria in the root nodules of $H$. tibetana. Frankia spp. can distribute not only nodules but also other tissues. By analyzing the community structure and diversity of endophytic bacteria in different tissues, the clonization and possible migration of Frankia in different tissues were discussed.

Methods: High-throughput sequencing of the V5-V7 region of 16S rRNA gene was used to study the diversity of Frankia spp. and other endophytic bacteria in root nodules, stems, branches, leaves, and seeds of H. tibetana,.

Results: The results showed that the richness and diversity indices of the community in the root nodules of $H$. tibetana were the highest, while the richness of endophytic bacterial community in seeds were the lowest, and diversity indices in the stems were the lowest. The diversity of endophytic bacterial communities in five types of tissues of $H$. tibetana

收稿日期: 2021-01-25; 接受日期: 2021-04-22

基金项目：国家自然科学基金(31360005)、甘肃省重点研发计划(20YF3FA043)和兰州市人才创新创业项目(2020-RC-84)

* 通讯作者 Author for correspondence. E-mail: zhangaimei@nwnu.edu.cn 
was different. Proteobacteria were the dominant phylum of the endophytic bacterial communities of five tissue types, Frankia was the dominant genus in root nodules, while Friedmanniella was the dominant genus in stems, and Stenotrophomonas was the dominant genus in branches, leaves, and seeds. The results also showed that Frankia could not only colonize in root nodules of $H$. tibetana, but also distributed in other tissues. There were different "species" of Frankia in the same tissue type of H. tibetana, and the same "species" of Frankia were also distributed in different tissues. In addition, functional endophytic bacteria existed in five tissue types of $H$. tibetana, which can fix nitrogen, promote the growth inhibit pathogens of host plants. Endophytic bacteria with nitrogen fixation function were mainly distributed in nodules, while those with growth-promoting and bacteriostatic functions were mainly distributed in branches and leaves of $H$. tibetana.

Conclusion: There were rich diversity of endophytic bacteria in five tissue types of $H$. tibetana, but the community structure and dominant population of each tissue were different, and different tissues could also colonize endophytic bacteria with multiple functions.

Key words: Hippophae tibetana; tissues; endophytic bacteria; diversity; Frankia spp.; functional strain

植物适应不同生境的特性与许多因素有关, 由 于植物内生菌的存在, 内生菌与寄主植物长期进化, 具有了一些特殊的生物学功能, 也能赋予寄主植物 适应不同气候和土壤的特性。西藏沙棘(Hippophae tibetana) 是典型的放线菌结瘤植物, 是高寒草甸区 广泛分布的一种先锋树种(Tian et al, 2002)。西藏沙 棘根系发达, 弗兰克氏菌能够侵染其根部形成根瘤, 其共生固氮作用大大增强了沙棘生态适应性(张爱 梅等, 2020a)。

植物内生菌与植物之间的关系已有很多报道。 首先, 植物内生菌可以定殖于几乎所有已检测的植 物体内, 具有广泛的寄主多样性(王志伟等, 2015; Afzal et al, 2019); 其次, 植物内生菌寄主植物组织 具有多样性, 不同或相同植物的不同器官部位中 (如根、茎、叶、花、种子和根瘤)均有内生菌的存 在(曹焜等, 2017; Beckers et al, 2017; 张爱梅等, 2019a; 张婷等, 2020); 第三, 植物内生菌具有丰富 的物种多样性, 涵盖植物内生真菌、内生放线菌和 内生细菌等, 已报道的约 90 余属 1,000 余种(蔡昕悦 等, 2020), 包括内生放线菌弗兰克氏菌属和内生细 菌假单胞菌属(Pseudomonas)等(宁楚涵等, 2019; Xu et al, 2019); 第四, 植物内生菌还具有丰富的功能 多样性, 包括固氮、促生和生物防治等(何玲敏和叶 建仁, 2014; Marag \& Suman, 2018)。

为进一步探究西藏沙棘根瘤中弗兰克氏菌属 (Frankia)的定殖和在不同组织中的迁移规律, 本研 究采用16S rRNA扩增子高通量测序技术分析了西 藏沙棘的根瘤、茎、叶、枝和种子等 5 种组织中弗 兰克氏菌属等内生细菌的群落结构及多样性的变 化规律和分布特征, 旨在丰富和完善西藏沙棘内生
细菌种质资源, 为进一步探究内生细菌与西藏沙棘 的相互作用及其开发应用奠定基础。

\section{材料与方法}

\section{1 样品采集及预处理}

采样地位于甘肃省天祝县抓喜秀龙乡金强河 地区, 经纬度为 $37^{\circ} 28^{\prime} \mathrm{N}$ 和 $104^{\circ} 09^{\prime} \mathrm{E}$, 样地海拔 2,950 m。于2018年9月21日在金强河河滩地的西藏 沙棘灌从典型生境中 (附录 1 ), 选取6株株高约为 40-65 cm的西藏沙棘植株, 分别采集其根瘤、茎、 枝、叶和种子。

样品带回实验室后先进行预处理。先对西藏沙 棘根瘤进行表面消毒, 操作如下: 选取新鲜幼嫩的 根瘤样品, 除去表面的泥沙等杂质, 称取 $1 \mathrm{~g}$ 根瘤组 织样品于 $10 \mathrm{~mL}$ 离心管中, 依次用自来水、蒸馏水和 无菌水冲洗; 然后用 $75 \%$ 的乙醇和 $1 \%$ 的次氯酸钠 溶液进行表面消毒(张爱梅等, 2010, 2018a, 2020b)。 再分别对茎、枝、叶和种子进行表面消毒, 操作如 下: 分别称取 $1 \mathrm{~g}$ 茎、枝、叶和种子于不同的 $10 \mathrm{~mL}$ 离心管中, 分别加 $5 \mathrm{~mL} 75 \%$ 的乙醇浸泡 $1 \mathrm{~min}$, 再 分别加 $5 \mathrm{~mL}$ 5\%的次氯酸钠浸泡 $5 \mathrm{~min}$ (张爱梅等, 2020b)。表面消毒后, 不同组织均用无菌水冲洗3次, 并吸取第三次无菌洗涤水 $150 \mu \mathrm{L}$, 将其涂布于牛肉 膏蛋白胨固体培养基, $37^{\circ} \mathrm{C}$ 条件下培养 $72 \mathrm{~h}$ 后, 检 验表面消毒效果。每处理3组平行, 检测无菌后的消 毒组织用于后续实验, 以确保表面消毒条件的合理 性(张爱梅等, 2020b)。

\section{2 总DNA的提取、PCR扩增及高通量测序 采用植物组织基因组DNA提取试剂盒NuClean Plant Genomic DNA Kit (Cwbio-tech, Beijing, China)}


提取西藏沙棘各组织总DNA, 并用 $1 \%$ 琼脂糖凝胶 检测DNA浓度和纯度。组织内生细菌16S rRNA V5-V7区的PCR扩增采用带Barcode的特异性引物 799F (5'-AACMGGATTAGATACCCKG-3') 和1193R (5'-ACGTCATCCCCACCTTCC-3')。PCR扩增采用 $50 \mu \mathrm{L}$ PCR扩增体系, 使用New England Biolabs公 司的缓冲液和高效保真酶, 确保扩增效率和准确 性。 PCR扩增反应条件为 $98^{\circ} \mathrm{C}$ 预变性 $5 \mathrm{~min}, 98^{\circ} \mathrm{C}$ 变 性30 s, $50^{\circ} \mathrm{C}$ 退火 $30 \mathrm{~s}, 72^{\circ} \mathrm{C}$ 延伸30 s, 25 个循环, 最 后 $72^{\circ} \mathrm{C}$ 延伸 $5 \mathrm{~min}$ 。部分 $\mathrm{PCR}$ 产物于 $2 \%$ 琼脂糖凝胶 电泳检测, 其余样品 $4^{\circ} \mathrm{C}$ 保存备用(张爱梅等, 2018b;

Kim et al, 2019)。

根据PCR产物浓度进行等量混样, 充分混匀后 使用 $2 \%$ 琼脂糖凝胶检测PCR产物, 对目的条带使 用Qiagen 公司的胶回收试剂盒回收产物。使用 TruSeq ${ }^{\circledR}$ DNA PCR-Free Sample Preparation Kit建库 试剂盒进行文库构建, 构建好的文库经过Qubit和 Q-PCR定量, 文库合格后, 使用Hiseq2500 PE250进 行上机测序。高通量测序工作由北京诺禾致源生物 信息科技有限公司完成。所有的测序原始数据已提 交到NCBI SRA (Sequence Read Archive), 并获得登 录号PRJNA718769。

\section{3 高通量测序数据处理与分析}

对测序得到的原始序列的低质量部分进行剪 切、PE Reads拼接、Tags过滤和Tags去嵌合体序列 后得到最终的有效序列(顾美英等, 2021)。之后利用 Uparse 7.0.1001 软件进行 OTU (operational taxonomic units)聚类和物种分类分析, 并将OTU和 物种注释结合, 再基于有效数据应用Mothur软件和 $\mathrm{R}$ 软件获得OTU表, 然后分别统计西藏沙棘5种不 同组织内生细菌OTU在各个分类水平上的数量。采 用QIIME对OTU表抽平后计算各分组样品的丰富 度及多样性指数, 并分别计算西藏沙棘 5 种组织中 内生细菌在门水平和属水平上的相对丰度。利用主 坐标分析(principal co-ordinate analysis)比较西藏沙 棘5种组织内生细菌群落之间的差异。

\section{2 结果}

\subsection{5 种不同组织内生细菌群落组成及差异}

对西藏沙棘5种不同组织样品进行总DNA提取,
通过PCR扩增其16S rRNA V5-V7区段, 对其高通 量测序后, 共得到内生细菌1,097,780条原始序列、 $1,030,448$ 条有效序列和 726,169 条注释序列。根瘤、 茎、枝、叶和种子样品的测序覆盖度分别为 $99.2 \%$ 、 $99.7 \% 、 99.7 \% 、 99.7 \%$ 和 $99.8 \%$ ，均为 $99 \%$ 以上，表 明其测序深度均达到分析要求且数据质量可靠。

\subsubsection{5种不同组织内生细菌OTU分布}

基于 $97 \%$ 相似度的分类水平，共注释得到 2,036 个内生细菌OTU。其中, 根瘤、茎、枝、叶和种子 中的内生细菌分别包含1,523、890、589、553和520 个 OTU, 5 种组织中共有的 OTU 为 172 个, 特有的 OTU在根瘤、茎、枝、叶和种子中分别为696、173、 63、48和64个(图1), 特有 OTU分别占总 OTU 的 $34.18 \% 、 8.50 \% 、 3.09 \% 、 2.36 \%$ 和 $3.14 \%$ 。以上结果 表明, 西藏沙棘5种不同组织特有的内生细菌群落 组成存在较大差异, 其中根瘤内生细菌特有OTU数 目最多, 其次是茎、枝和种子, 叶中最少。

在 $97 \%$ 相似度下对所有序列进行OTU划分, 对 OTU代表物种进行物种注释, 从门、纲、目、科和 属不同分类单元水平进行分析, 西藏沙棘5种不同 组织中内生细菌的群落组成结果如表1所示。从结 果可以看出, 西藏沙棘5种不同组织中检测到的各 分类单元的内生细菌的群落组成不同: 根瘤中含有 的内生细菌门和属的种类数量均为最多, 种子中含 有的门水平的种类数最少, 叶中含有的属水平的种 类数最少。

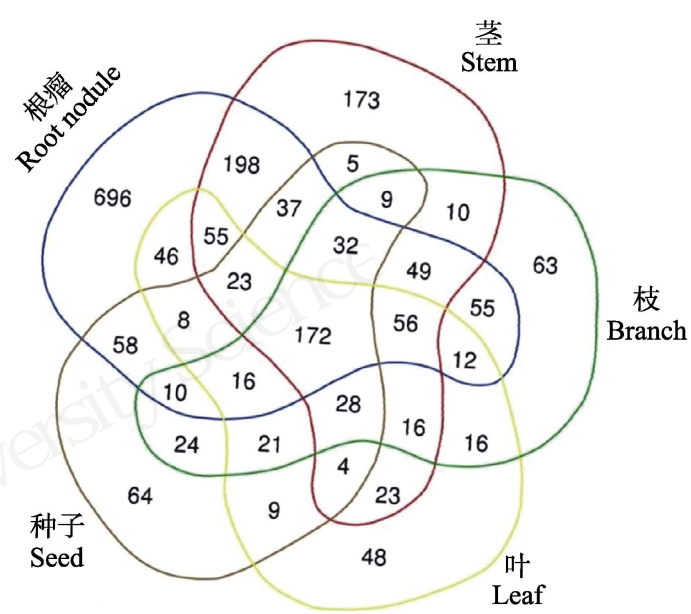

图1 西藏沙棘5种不同组织内生细菌群落OTU分布韦恩图 Fig. 1 Venn diagram of OTU distribution of endophytic bacterial community detected in five tissues of Hippophae tibetana 
表1 西藏沙棘5种组织内生细菌各分类单元的群落组成 Table 1 Endophytic bacterial community in five tissues of Hippophae tibetana at each classification level

\begin{tabular}{|c|c|c|c|c|c|}
\hline 样品 Sample & 门 & Phylum 纲 & Class 目 & Order 科 Family & 属 Genus \\
\hline $\begin{array}{l}\text { 根瘤 } \\
\text { Root nodule }\end{array}$ & 22 & 33 & 69 & 113 & 203 \\
\hline 茎 Stem & 18 & 28 & 59 & 102 & 185 \\
\hline 枝 Branch & 18 & 29 & 58 & 99 & 191 \\
\hline 叶 Leaf & 18 & 24 & 49 & 91 & 171 \\
\hline 种子 Seed & 16 & 25 & 55 & 96 & 172 \\
\hline
\end{tabular}

表2 西藏沙棘5种不同组织内生细菌群落丰富度及多样性 指数

Table 2 Richness and diversity indices of endophytic bacteria in five tissues of Hippophae tibetana

\begin{tabular}{lllll}
\hline $\begin{array}{l}\text { 样品 } \\
\text { Sample }\end{array}$ & $\begin{array}{l}\text { ACE指数 Chao1指数 } \\
\text { ACE index Chao1 index }\end{array}$ & $\begin{array}{l}\text { Shannon指数 } \\
\text { Shannon index }\end{array}$ & $\begin{array}{l}\text { Simpson指数 } \\
\text { Simpson index }\end{array}$ \\
\hline $\begin{array}{l}\text { 根瘤 } \\
\text { Root nodule }\end{array}$ & $1,044 \pm 197^{\mathrm{a}} 1,040 \pm 197^{\mathrm{a}}$ & $4.633 \pm 2.673^{\mathrm{ab}}$ & $0.700 \pm 0.283^{\mathrm{b}}$ \\
茎 Stem & $605 \pm 76^{\mathrm{a}}$ & $575 \pm 78^{\mathrm{a}}$ & $6.107 \pm 0.173^{\mathrm{a}}$ & $0.969 \pm 0.004^{\mathrm{a}}$ \\
枝 Branch & $307 \pm 42^{\mathrm{ab}}$ & $285 \pm 34^{\mathrm{b}}$ & $2.820 \pm 0.664^{\mathrm{b}}$ & $0.646 \pm 0.147^{\mathrm{b}}$ \\
叶 Leaf & $296 \pm 63^{\mathrm{b}}$ & $279 \pm 60^{\mathrm{b}}$ & $3.340 \pm 1.337^{\mathrm{a}}$ & $0.753 \pm 0.250^{\mathrm{ab}}$ \\
种子 Seed $^{2} 265 \pm 2^{\mathrm{b}}$ & $260 \pm 7^{\mathrm{b}}$ & $3.007 \pm 0.245^{\mathrm{b}}$ & $0.751 \pm 0.020^{\mathrm{b}}$
\end{tabular}

同一列不同小写字母表示群落间差异显著 $(P<0.05)$

Different lowercase letters in the same column indicated significant difference between communities $(P<0.05)$

\subsubsection{5种不同组织内生细菌群落丰富度与多样性}

西藏沙棘5种不同组织内生细菌群落的丰富度 及多样性指数如表 2 所示。 5 种组织内生细菌群落的 物种丰富度指数(ACE指数和Chao1指数)和多样性 指数(Shannon指数和Simpson指数) 存在显著差异。 其中, 根瘤内生细菌群落丰富度最高, 种子内生细 菌群落丰富度最低, 茎内生细菌群落多样性最低。

\subsubsection{5种不同组织内生细菌的优势种群}

从西藏沙棘5种不同组织样品共获得 30 个门和 一些未确定类群, 图2A所示为相对丰度位于前 10 的内生细菌门。其中变形菌门均为优势门, 它在西 藏沙棘的根瘤、茎、枝、叶和种子中的相对丰度分 别为 $35.38 \% 、 57.23 \% 、 92.24 \% 、 77.75 \%$ 和 $51.54 \%$; 放 线菌门的相对丰度分别为 $59.52 \% 、 36.12 \% 、 2.61 \%$ 、 $8.92 \%$ 和 $1.69 \%$ 。可见, 变形菌门在西藏沙棘的枝中 丰富度最高, 而放线菌门在根瘤中丰富度最高。

从属水平分析, 西藏沙棘5种不同组织样品共 获得369个属和一些未确定类群, 图2B所示为相对 丰度位于前 10 的内生细菌属。相对丰度位于前 10 的
属隶属于放线菌门、变形菌门和产氧光细菌门, 其 中, 弗兰克氏菌属为西藏沙棘根瘤内生细菌群落的 绝对优势属, 其相对丰度为 $47.63 \%$; 弗莱德门菌属 (Friedmanniella) 为茎内生细菌群落的优势属, 相对 丰度为 $10.22 \%$; 寡养单胞菌属(Stenotrophomonas) 为枝、叶和种子内生细菌群落的优势属, 相对丰度 分别为 $51.74 \% 、 32.62 \%$ 和 $35.69 \%$ 。

\subsubsection{5种不同组织内生细菌群落组成的差异}

西藏沙棘5种不同组织内生细菌群落组成主坐 标分析结果如图3所示。结果表明, 主坐标成分 1 (PCoA1)和主坐标成分 2 (PCoA2)的样品差异性贡 献率分别为 $43.13 \%$ 和 $19.19 \%$, 合计为 $62.32 \%$, 是差 异的主要来源。西藏沙棘5种组织内生细菌群落多 样性差异较大, 其中, 根瘤内生细菌群落分布在第 二象限, 茎内生细菌群落分布在第三象限, 枝、叶 和种子内生细菌群落分布在第一和第四象限。

\section{2 弗兰克氏菌的相对丰度和多样性}

通过对西藏沙棘5种不同组织内生细菌的16S rRNA V5-V7区高通量测序后发现, 弗兰克氏菌不 仅能够在西藏沙棘的根瘤中定殖, 也能够分布于其 他组织。弗兰克氏菌属在西藏沙棘不同组织中的相 对丰度如图4所示。

由图4可见，弗兰克氏菌在西藏沙棘5种不同组 织根瘤、茎、枝、叶和种子中的相对丰度分别为 $47.63 \% 、 0.14 \% 、 0.02 \% 、 0.03 \%$ 和 $0.03 \%$ 。可见，根 瘤是弗兰克氏菌定殖的主要场所, 其他组织中也有 少量的弗兰克氏菌分布。

弗兰克氏菌在5种不同组织中也表现出了丰富 的物种多样性。通过高通量测序发现, 弗兰克氏菌 属在西藏沙棘组织中共检测到7种不同的OTUs, 分 别为OTU3、OTU88、OTU241、OTU1030、OTU1524、 OTU1958和OTU2669, 统计各个OTU在不同样品中 序列数及相对丰度, 结果如表 3 所示。

从表3可知, 根瘤中弗兰克氏菌属物种多样性 最为丰富, 包含所有检测到的7种OTU; 茎中包含 4 种弗兰克氏菌属的OTU, 枝中仅包含2种, 叶和种 子均包含3种。以上结果表明, 在西藏沙棘同一种组 织中, 存在不同种类的弗兰克氏菌属的“种”; 而在 西藏沙棘不同组织中也分布有弗兰克氏菌属的相 同“种”。 


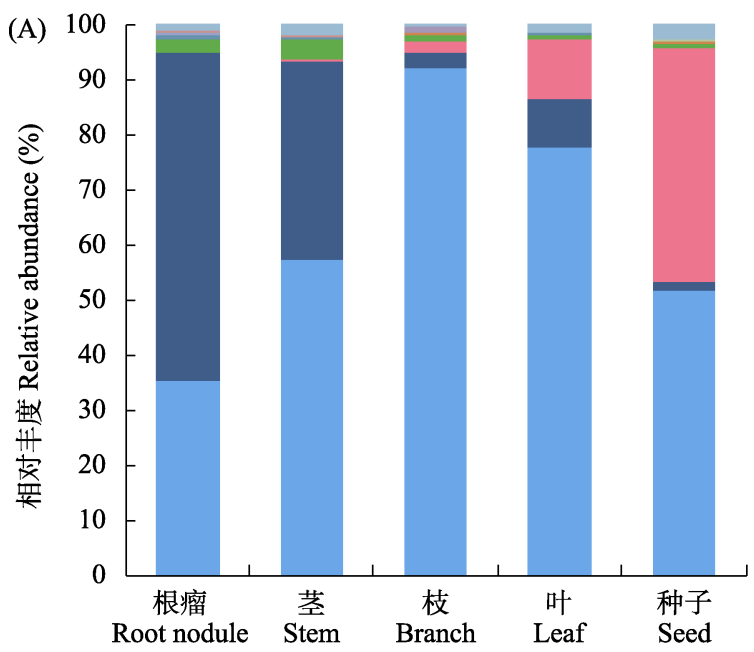

异常球菌-栖热菌门 Deinococcus-Thermus

硝化螺旋菌门 Nitrospirae

n 浮霉菌门 Planctomycetes

口拟杆菌门 Bacteroidetes

产氧光细菌门

Oxyphotobacteria

芽单胞菌门 Gemmatimonadetes 变形菌门 Proteobacteria

后壁菌门 Firmicutes

酸杆菌门 Acidobacteria

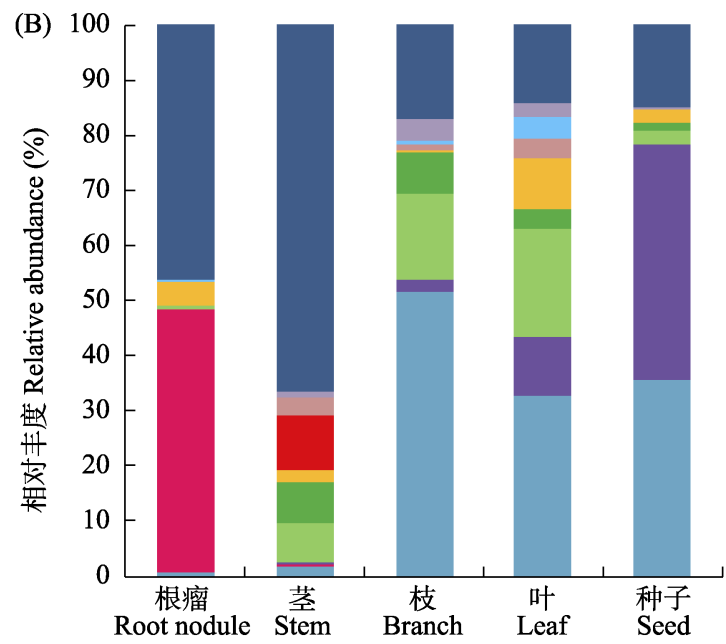

- 马赛菌属 Massilia 鞘氦醇单胞菌属 Sphingomonas

口叶居菌属 Frondihabitans 未 未鉴定-产氧光细菌

- 动球菌属 Kineococcus Unidentified oxyphotobacteria

弗莱德门菌属囲兰克氏菌属 Frankia

Friedmanniella

假单胞菌属 Pseudomonas 其他 Others

口 甲基杆菌属 Methylobacterium

图2 西藏沙棘5种不同组织内生细菌相对丰度。(A)门水平; (B)属水平。

Fig. 2 Relative abundance of endophytic bacteria in five tissues of Hippophae tibetana. (A) Phylum level; (B) Genus level.

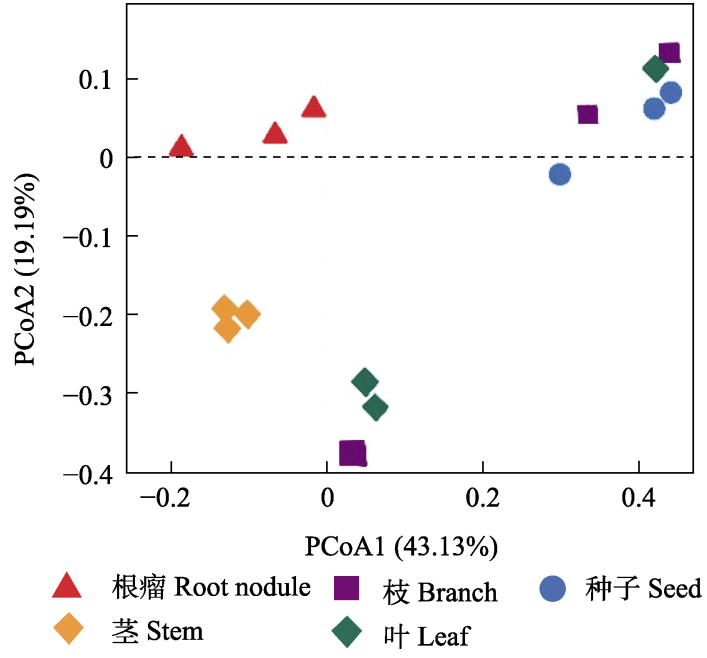

图3 西藏沙棘5种不同组织内生细菌群落PCoA图

Fig. 3 PCoA analysis of endophytic bacterial community in five tissues of Hippophae tibetana

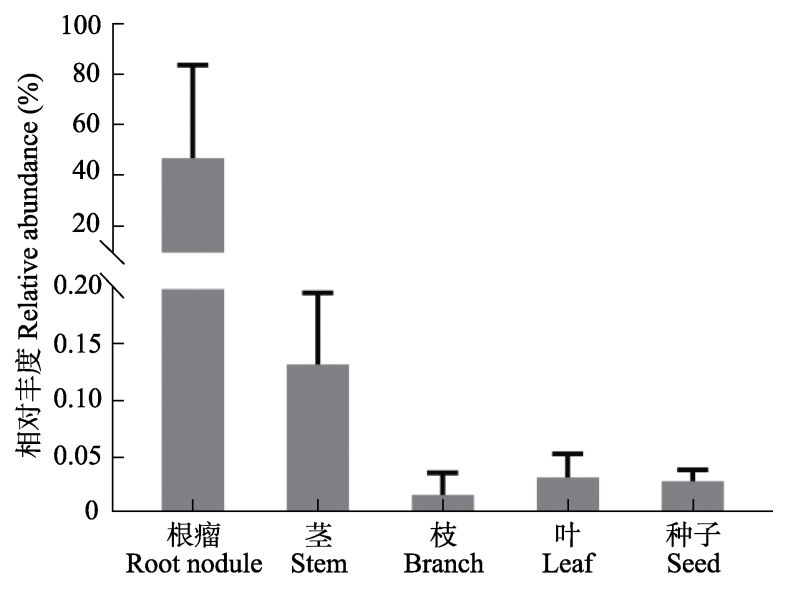

图4 弗兰克氏菌属在西藏沙棘5种不同组织中的相对丰度 Fig. 4 Relative abundances of Frankia in five tissues of Hippophae tibetana

表3 弗兰克氏菌OTU在西藏沙棘5种不同组织内的分布

Table 3 Distribution of Frankia OTU in five tissues of Hippophae tibetana

\begin{tabular}{llllllll}
\hline 样品 Sample & OTU3 & OTU88 & OTU241 & OTU1030 & OTU1524 & OTU1958 & OTU2669 \\
\hline 根瘤 Root nodule & $45.04 \%$ & $1.07 \%$ & $1.47 \%$ & $0.01 \%$ & $0.03 \%$ & $0.01 \%$ & $0.01 \%$ \\
茎 Stem & $0.12 \%$ & $0.01 \%$ & $0.01 \%$ & 0 & $0.01 \%$ & 0 & 0 \\
枝 Branch & $0.02 \%$ & 0 & $0.01 \%$ & 0 & 0 & 0 & 0 \\
叶 Leaf & $0.02 \%$ & $0.01 \%$ & $0.01 \%$ & 0 & 0 & 0 & 0 \\
种子 Seed & $0.02 \%$ & $0.01 \%$ & $0.01 \%$ & 0 & 0 & 0 & 0 \\
\hline
\end{tabular}


(A)
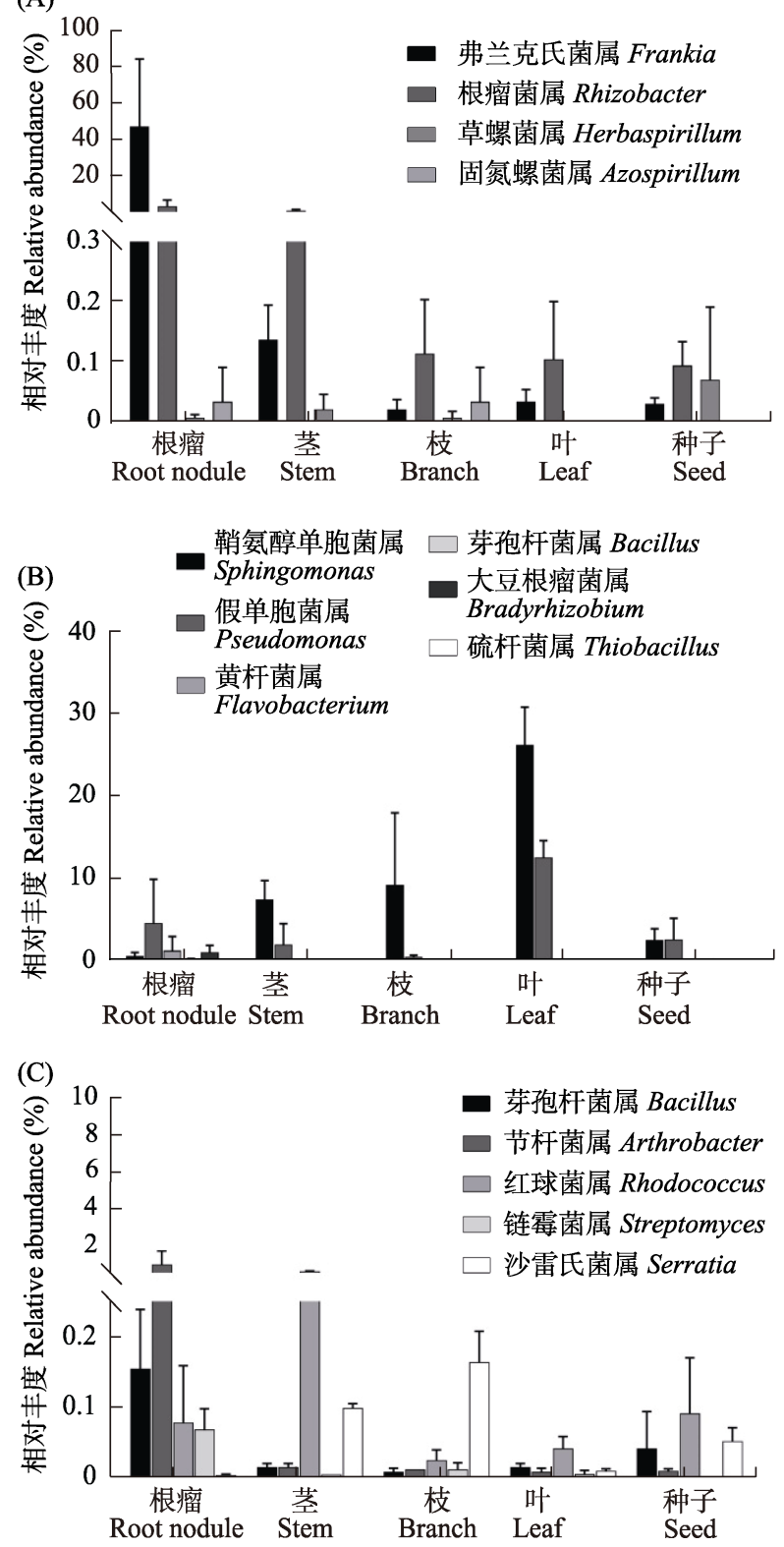

图5 西藏沙棘5种不同组织中功能内生细菌的种类及丰度。 (A)固氮; (B) 促生; (C)抑制寄主植物病原体。

Fig. 5 Classification and relative abundance of functional endophytic bacteria in five tissues of Hippophae tibetana. (A) Nitrogen fixation; (B) Growth-promoting; (C) Inhibiting plant pathogens.

\section{3 西藏沙棘5种不同组织中的功能内生细菌}

\subsection{1 具有固氮功能的内生细菌}

本研究基于高通量测序结果, 汇总了西藏沙棘 5 种组织内生细菌在属水平上的主要功能菌(图5)。 结果表明, 具有固氮作用的内生细菌主要有弗兰克 氏菌属、根瘤菌属 (Rhizobacter)、草螺菌属 (Herbaspirillum) 和固氮螺菌属 (Azospirillum) (图
$5 A)$ 。根瘤是固氮内生细菌分布的主要组织, 前述4 种固氮功能菌在根瘤中均有定殖, 其中丰度最高的 是弗兰克氏菌属; 草螺菌属在除了叶子的4种组织 中均有分布, 在种子内的相对丰度最高, 达到 $0.08 \%$; 而在茎、枝和叶中相对丰度最高的固氮菌均 为根瘤杆菌属, 相对丰度分别为 $1.10 \% 、 0.11 \%$ 和 $0.10 \%$ 。

\subsection{2 具有促生功能的内生细菌}

具有促生作用的内生细菌主要有鞘氨醇单胞 菌属(Sphingomonas)、假单胞菌属(Pseudomonas)、 黄杆菌属(Flavobacterium)、芽狍杆菌属(Bacillus)、 大豆根瘤菌属 (Bradyrhizobium) 和硫杆菌属 (Thiobacillus) (图5B)。其中, 鞘氨醇单胞菌属在茎、 枝和叶中均为相对丰度最高的属, 其相对丰度分别 为 $7.34 \% 、 15.81 \%$ 和 $19.45 \%$; 而根瘤和种子中相对 丰度最高的属均为假单胞菌属, 其相对丰度分别为 4.45\%和 $2.51 \%$; 硫杆菌属只分布于西藏沙棘的种 子中, 相对丰度为 $0.01 \%$ 。

\subsection{3 具有抑制植物病原体功能的内生细菌}

具有抑菌作用的内生细菌主要为芽孢杆菌属、 节杆菌属(Arthrobacter)、红球菌属(Rhodococcus)、 链霉菌属(Streptomyces)和沙雷氏菌属(Serratia)等 (图5C)。西藏沙棘茎、叶和种子内相对丰度最高的 均为红球菌属, 其丰度分别为 $0.37 \% 、 0.04 \%$ 和 $0.42 \%$; 而根瘤中相对丰度最高的为节杆菌属, 其 相对丰度为 $0.93 \%$, 枝中相对丰度最高的属为沙雷 氏属，其相对丰度为 $0.11 \%$ 。

\section{3 讨论}

本研究基于高通量测序技术对西藏沙棘根瘤、 茎、枝、叶和种子中内生细菌的多样性进行了研究。 结果表明, 5种不同组织中均定殖着丰富的内生细 菌, 但内生细菌的分布存在一定的组织差异性: 根 瘤中含有的内生细菌种类数最多, 种子中群落丰富 度最低, 茎中群落多样性最低。从内生细菌群落组 成来看, 西藏沙棘5种组织中的共有门为变形菌门, 5种组织中的共有属达 73 个, 可见, 5种组织中内生 细菌具有一定的相似性。但5种组织中的特有门和 特有属均存在一定差异: 根瘤中有 49 个特有属, 茎 中有 12 个特有属, 枝中有 16 个特有属, 叶中有 11 个 特有属, 而种子中有 11 个特有属。此外, 各组织中 的优势属有所不同, 其中, 根瘤组织优势属为弗兰 
克氏菌属, 枝和叶组织优势属为寡养单胞菌属, 茎 组织优势属分别为弗莱德门菌属, 种子中的优势属 为未鉴定产氧光细菌。可见, 西藏沙棘内生细菌中 有些种类具有组织特异性, 而另一些则广泛分布 (沙月霞, 2018; 陈志远等, 2019)。已有研究表明, 植 物内生菌具有组织专一性, 且植物不同组织间内生 菌多样性结构随植物的不同具有一定的差异(许国 琪等, 2020)。本研究中的西藏沙棘作为高寒高海拔 地区的特有物种之一, 其不同组织中的内生细菌的 差异可能还与其所处的特殊生境有关, 在长期适应 环境的过程中, 形成了自身独特的内生细菌群落组 成。

根瘤是西藏沙棘与弗兰克氏菌形成的共生固 氮结构(Chaia et al, 2010)。本研究发现, 西藏沙棘的 根瘤中不仅存在着弗兰克氏菌, 还存在着其他非弗 兰克氏内生细菌, 且弗兰克氏菌的相对丰度为 $47.63 \%$ 。此外, 本研究首次发现, 弗兰克氏菌不仅 能够在西藏沙棘的根瘤中定殖, 还能够分布于西藏 沙棘的其他组织, 且不同组织中的弗兰克氏菌属具 有不同的种类。基于OTU分析的结果表明, 弗兰克 氏菌属在西藏沙棘组织中共检测到7个不同的OTU, 其中OTU3和OTU241能够分布于被检测的所有组 织, OTU88在枝中未检测到分布, OTU1958能够分 布于根瘤和茎, 而OTU1030、OTU1958和OTU2669 仅分布于根瘤。这些研究结果均表明, 西藏沙棘不 同组织中可定殖不同的弗兰克氏菌, 而大多数弗兰 克氏菌可能具有一定的组织专化性。

本课题组前期对生长于甘南高寒地区的西藏 沙棘根瘤内生菌进行高通量测序发现, 根瘤中弗兰 克氏菌属的相对丰度为 $29.03 \% \pm 0.80 \%$ (张爱梅等, 2018b), 可见, 生长于天祝金强河的西藏沙棘根瘤 中弗兰克氏菌的相对丰度大于生长于甘南的西藏 沙棘, 这可能与它们所处的海拔、生境不同有关。 但两个不同地区分布的西藏沙棘根瘤内生细菌群 落结构相似(张爱梅等, 2018b), 可见, 植物组织间 内生菌多样性还与植物种类有关(许国琪等, 2020)。

大量研究结果表明, 植物内生菌具有丰富的功 能多样性(Hallmann et al, 1997), 对寄主的生长发挥 着重要的作用(杜晓宁等, 2015)。本研究中西藏沙棘 5 种不同组织的内生细菌中具有固氮、促生和生物 防治功能的内生细菌具有丰富的功能多样性。其中, 根瘤中具有固氮作用的内生菌不仅仅是弗兰克氏
菌属(宋成军等, 2009; 张爱梅, 2018b), 还包括根瘤 杆菌属、草螺菌属和固氮螺菌属; 具有促生长作用 的内生细菌包括鞘氨醇单胞菌属、假单胞菌属、黄 杆菌属、芽狍杆菌属、大豆根瘤菌属和硫杆菌属; 具 有抑菌作用的内生细菌主要为芽孢杆菌属、节杆菌 属、红球菌属、链霉菌属和沙雷氏菌属等。具有固 氮作用的内生细菌主要分布于根瘤中, 具有促生作 用和具有抑制植物病原体功能的内生细菌主要分 布于叶内。可见，西藏沙棘的同种组织中能够定殖 不同功能的内生细菌, 而具有同种功能的内生细菌 又能够定殖在不同的组织中。对于沙棘属植物内生 菌功能的研究, 本课题组前期通过纯培养方法, 从 中国沙棘根瘤中分离得到 1 株对多种病原微生物具 有抑菌效果的蕈状芽孢杆菌(Bacillus mycoides), 且 其对黄瓜的生长具有明显的促进作用(张爱梅等, 2019a)。后续研究可将纯培养方法和基于免培养的 高通量测序相结合，定向地从沙棘的不同组织中富 集培养具有特定功能的内生菌株, 以丰富西藏沙棘 具有的独特的功能内生菌资源。

\section{ORCID}

孔维宝 (1) https://orcid.org/0000-0001-6151-5962

杨颖丽 (D) https://orcid.org/0000-0002-0748-9836

\section{参考文献}

Afzal I, Shinwari ZK, Sikandar S, Shahzad S (2019) Plant beneficial endophytic bacteria: Mechanisms, diversity, host range and genetic determinants. Microbiological Research, 221, 36-49.

Beckers B, Beeck MOD, Weyens N, Boerjan W, Vangronsveld J (2017) Structural variability and niche differentiation in the rhizosphere and endosphere bacterial microbiome of field-grown poplar trees. Microbiome, 5, 25.

Cai XY, Liu YC, Xie ZH, Chen YL, Liu RJ (2020) Research advances in mutualistic symbiotic microbes diversities. Microbiology China, 47, 3899-3917. (in Chinese with English abstract) [蔡昕悦, 刘耀臣, 解志红, 陈应龙, 刘润 进 (2020) 互惠共生微生物多样性研究概况. 微生物学 通报, 47, 3899-3917.]

Cao K, Wang XN, Sun YF, Li ZW, Pan DM, Zhao Y (2017) Research progress on endophytic bacterial diversity and biocontrol of plant roots. Agriculture and Technology, 37(17), 1-3, 5. (in Chinese) [曹焜, 王晓楠, 孙宇峰, 李振 伟, 潘冬梅, 赵越 (2017) 植物根部内生细菌多样性及其 生防作用研究进展. 农业与技术, 37(17), 1-3, 5.]

Chaia EE, Wall LG, Huss-Danell K (2010) Life in soil by the 
actinorhizal root nodule endophyte Frankia. A review. Symbiosis, 51, 201-226.

Chen ZY, Liu J, Yang XP, Liu M, Wang Y, Zhang ZB, Zhu D (2019) Community composition and diversity of cultivable endophytic bacteria isolated from Dongxiang wild rice. Biodiversity Science, 27, 1320-1329. (in Chinese with English abstract) [陈志远, 刘珺, 杨星鹏, 刘梦, 汪涯, 张 志斌, 朱笃 (2019) 东乡野生稻可培养内生细菌群落组 成及多样性. 生物多样性, 27, 1320-1329.]

Du XN, Xu HJ, Huang PP, Dai JX (2015) Diversity and antimicrobial activity of endophytic bacteria isolated from Lycium barbarum of Ningxia. Microbiology China, 42, 1779-1787. (in Chinese with English abstract) [杜晓宁, 徐 惠娟, 黄盼盼, 代金霞 (2015) 宁夏枸杞内生细菌的多样 性及其抑菌活性研究. 微生物学通报, 42, 1779-1787.]

Gu MY, Gulinisha S, Zhang ZD, Zhu J, Liu XJ, Tang QY, Outikuer M, Song SQ, Feng L, Tang GM, Xu WL (2021) Diversity and function analysis of endophytic bacterial community in different tissues of Lycium ruthenicum Murr. Acta Microbiologica Sinica, 61, 152-166. (in Chinese with English abstract) [顾美英, 古丽尼沙·沙依木, 张志东, 朱 静, 刘晓静, 唐琦勇, 欧提库尔·玛合水提, 宋素琴, 冯雷, 唐光木, 徐万里 (2021) 黑果枸杞不同组织内生细菌群 落多样性. 微生物学报, 61, 152-166.]

Hallmann J, Quadt-Hallmann A, Mahaffee WF, Kloepper JW (1997) Bacterial endophytes in agricultural crops. Canadian Journal of Microbiology, 43, 895-914.

He LM, Ye JR (2014) Endophytic bacteria: Research advances and biocontrol applications. Journal of Nanjing Forestry University (Natural Sciences Edition), 38, 153-159. (in Chinese with English abstract) [何玲敏, 叶建仁 (2014) 植 物内生细菌及其生防作用研究进展. 南京林业大学学报 (自然科学版), 38, 153-159.]

Kim H, Rim SO, Bae H (2019) Antimicrobial potential of metabolites extracted from ginseng bacterial endophyte Burkholderia stabilis against ginseng pathogens. Biological Control, 128, 24-30.

Marag PS, Suman A (2018) Growth stage and tissue specific colonization of endophytic bacteria having plant growth promoting traits in hybrid and composite maize (Zea mays L.). Microbiological Research, 214, 101-113.

Ning CH, Li WB, Liu RJ (2019) Research advances in plant symbiotic actinomyces. Chinese Journal of Ecology, 38, 256-266. (in Chinese with English abstract) [宁楚涵, 李文 涁, 刘润进 (2018) 植物共生放线菌研究进展. 生态学杂 志, 38, 256-266.]

Sha YX (2018) Diversity of bacterial endophytic community in different rice tissues. Acta Microbiologica Sinica, 58, 2216-2228. (in Chinese with English abstract) [沙月霞 (2018) 不同水稻组织内生细菌的群落多样性. 微生物学 报, 58, 2216-2228.]

Song CJ, Ma KM, Fu BJ, Qu LY, Liu Y (2009) A review on the functions of nitrogen-fixers in terrestrial ecosystems.
Acta Ecologica Sinica, 29, 869-877. (in Chinese with English abstract) [宋成军, 马克明, 傅伯杰, 曲来叶, 刘杨 (2009) 固氮类植物在陆地生态系统中的作用研究进展. 生态学报, 29, 869-877.]

Tian CJ, He XY, Zhong Y, Chen JK (2002) Effects of VA mycorrhizae and Frankia dual inoculation on growth and nitrogen fixation of Hippophae tibetana. Forest Ecology and Management, 170, 307-312.]

Wang ZW, Ji YL, Chen YG (2015) Studies and biological significances of plant endophytes. Microbiology China, 42, 349-363. (in Chinese with English abstract) [王志伟, 纪燕 玲, 陈永敢 (2015) 植物内生菌研究及其科学意义. 微生 物学通报, 42, 349-363.]

Xu GQ, Liu YX, Cao PX, Liu X (2021) Core microflora and endophytic interaction network of Oxytropis glacialis in Qinghai-Tibet Plateau. Microbiology China, 47, 2746-2758 (in Chinese with English abstract) [许国琪, 刘怡萱, 曹鹏 熙, 刘星 (2021) 青藏高原冰川棘豆(Oxytropis glacialis) 内生菌核心微生物组的界定及其互作网络分析. 微生物 学通报, 47, 2746-2758.]

Xu WF, Wang F, Zhang M, Ou T, Wang RL, Strobel G, Xiang ZH, Zhou ZY, Xie J (2019) Diversity of cultivable endophytic bacteria in mulberry and their potential for antimicrobial and plant growth-promoting activities. Microbiological Research, 229, 126328.

Zhang AM, Niu SQ, Sun K, Cao WX, Da WY (2010) Study on the root nodules features of Hippophae and Frankia isolation. Grassland and Turf, 30(2), 43-46. (in Chinese with English abstract) [张爱梅, 牛世全, 孙坤, 曹文侠, 达 文燕 (2010) 沙棘属植物结瘤特性及Frankia根瘤菌分离. 草原与草坪, 30(2), 43-46.]

Zhang AM, Han XY, Sun K, Zhang SH, Kong WB, Niu SQ, Zhu XT (2018a) Root nodules endophytic and rhizosphere soil bacteria diversity of Hippophae rhamnoides subsp. sinensis based on high-throughput sequencing. Grassland and Turf, 38(2), 49-55. (in Chinese with English abstract) [张爱梅, 韩雪英, 孙坤, 张世虎, 孔维宝, 牛世全, 朱学 泰 (2018a) 高通量测序分析中国沙棘根瘤与根际土壤细 菌多样性. 草原与草坪, 38(2), 49-55.]

Zhang AM, Han XY, Zhang SH, Sun K, Wu JY, Yu J, Guo BM (2018b) Diversity of root nodule endophytic bacteria in Hippophae tibetana at different altitudes in Gannan area. Biotic Resources, 40, 114-119. (in Chinese with English abstract) [张爱梅, 韩雪英, 张世虎, 孙坤, 吴菊艳, 于杰, 郭保民 (2018b) 甘南高寒地区不同海拔西藏沙棘根瘤内 生菌多样性. 生物资源, 40, 114-119.]

Zhang AM, Han XY, Wang J, Kong WB, Niu SQ, Zhu XT (2019a) Diversity of endophytic bacteria in root nodules of Hippophae rhamnoides in the Maxian Mountains. Acta Ecologica Sinica, 39, 294-301. (in Chinese with English abstract) [张爱梅, 韩雪英, 王嘉, 孔维宝, 牛世全, 朱学 泰 (2019a) 马衔山中国沙棘根瘤内共生细菌多样性研究. 生态学报, 39, 294-301.] 
Zhang AM, Wu JY, Han XY, Kong WB (2019b) Screening and identification of antagonistic and plant-growth promoting endophytic bacteria from Seabuckthorn nodules. Microbiology China, 46, 1041-1051. (in Chinese with English abstract) [张爱梅, 吴菊艳, 韩雪英, 孔维宝 (2019b) 沙棘根瘤内生细菌中抑菌促生菌株的篮选和鉴 定. 微生物学通报, 46, 1041-1051.]

Zhang AM, Yin YR, Sun K (2020a) Research progress in Frankia spp. associated with Hippophae L. Microbiology China, 47, 3933-3944. (in Chinese with English abstract) [张爱梅, 殷一然, 孙坤 (2020) 沙棘属植物弗兰克氏菌 研究进展. 微生物学通报, 47, 3933-3944.]

Zhang AM, Guo BM, Han XY, Li XR (2020b) Diversity of endophytic bacteria in seeds of Hippophae rhamnoides subsp. sinensis in two different habitats. Acta Ecologica Sinica, 40, 5247-5257. (in Chinese with English abstract) [张爱梅, 郭保民, 韩雪英, 李曦舟 (2020b) 两种不同生 境中国沙棘种子内生细菌的多样性. 生态学报, 40, 5247-5257.]

Zhang T, Li Y, Xiong J, Xu XH, Lan CH, Tian BY (2020) Community composition and differential analysis of endophytic bacteria in different niches of tomato. Genomics and Applied Biology, 39, 5558-5566. (in Chinese with English abstract) [张婷, 黎烨, 熊娟, 许小红, 蓝灿华, 田 宝玉 (2020) 番茄不同生态位内生菌的菌群结构组成和 差异性分析, 39, 5558-5566.]

(责任编委：东秀珠 责任编辑：时意专)

\section{附录 Supplementary Material}

\section{附录1 西藏沙棘生境图}

Appendix 1 The habitat of Hippophae tibetana

http://www.biodiversity-science.net/fileup/PDF/2021034-1.pdf 
张爱梅, 殷一然, 孔维宝, 朱学泰, 杨颖丽 (2021) 西藏沙棘 5 种不同组织内生细菌多样性. 生物多样性, 29 , $1236-1244$.

http://www.biodiversity-science.net/CN/10.17520/biods.2021034

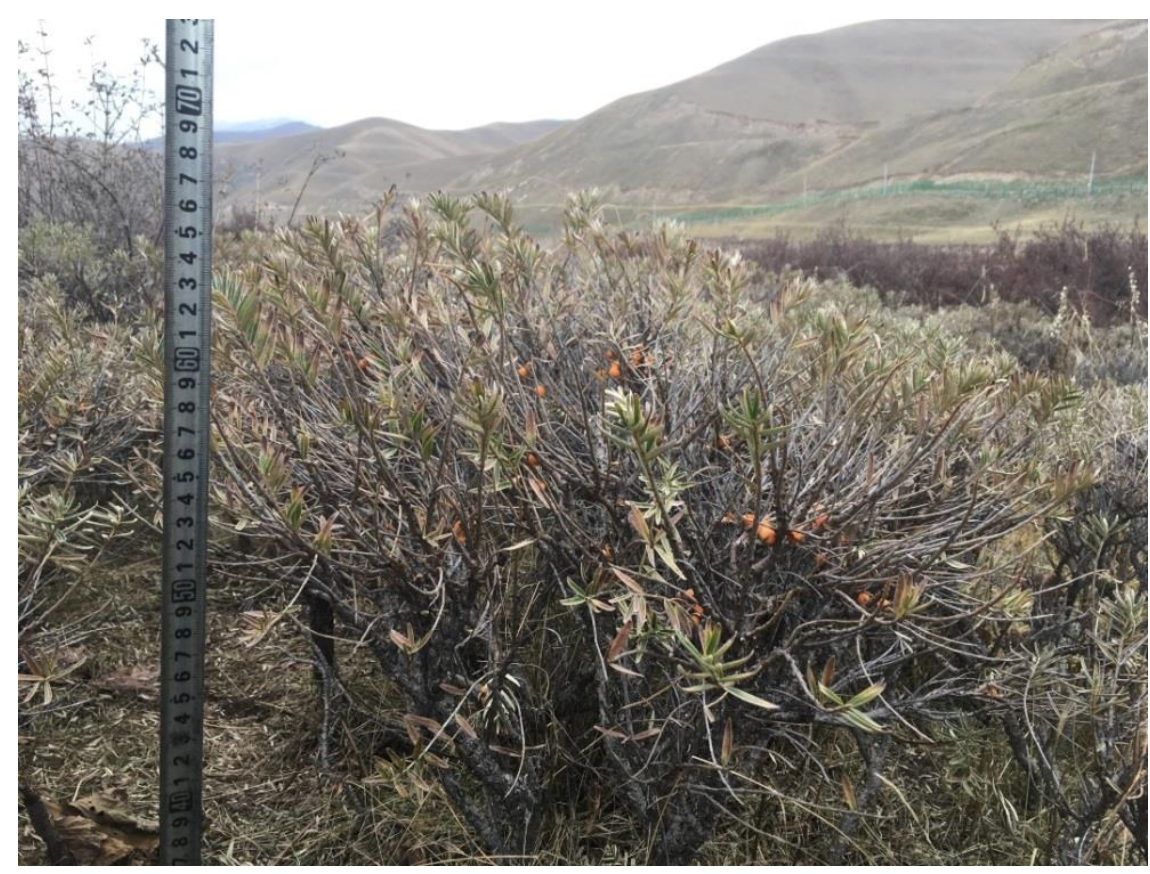

附录1 西藏沙棘生境图

Appendix 1 The habitat of Hippophae tibetana 